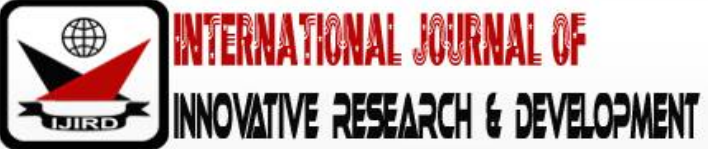

ISSN 2278 - 0211 (Online)

\section{Readiness for Change, Coping with Change and Turnover Intention: Evidence from Ghanaian Universities}

\author{
Augustina Adei Ashie \\ Lecturer, Department of Human Resource Management \\ University of Education, Winneba, Ghana \\ Dr. B. B. B. Bingab \\ Lecturer, Department of Human Resource Management \\ University of Education, Winneba, Ghana \\ Linda Qaugraine \\ Lecturer, Department of Human Resource Management \\ University of Education, Winneba, Ghana
}

\begin{abstract}
:
External factors, such as government regulations, have pushed organizations into change. For this reason, readiness for change and coping with change rose as a key construct in order for organizations to respond quickly and successfully to change. However, there is a lack of empirical evidence on how readiness for change and coping with change promotes changes in employee's behaviours. The study sought to test the extent to which readiness for change influences employee turnover intention after the appointment of a new management team at the University of Education, Winneba in the year 2018. The quantitative methodology was employed using survey instrument. Convenience sampling was used to select approximately 107 respondents made up of both academic and non-academic staff of the University of Education, Winneba for the study. Readiness for change had a significant negative influence on turnover intention. Coping with change on the other hand was observed to mediate the relationship between readiness for change and turnover intention. These results lay emphasis on the importance of crafting a readiness for change message and the role played by employee's ability to cope with change.
\end{abstract}

Keywords: Readiness for change, coping with change, turnover intention, personal valence, change appropriateness, selfefficacy

\section{Introduction}

Change is an inevitable phenomenon in today's business world. According to Conner, (1992), Organizations today are facing more change than ever before. This is so due to the fact that these organizations are striving to retain their competitive advantage, and this has resulted in most organizations reorganizing, downsizing, and implementing new technology. A survey conducted by the Bureau of National Affairs (1996) revealed that organizational change was a major concern for more than a third of the 396 organizations surveyed. Dyer, (1985) posits that external events and crises trigger changes far more than planned events. However, the outcome of these change will be shaped by internal processes within the organization (Neves, 2009). The processes adopted to implement the change, organizational member's readiness and reaction to the change to a large extent shape the outcome of the change process.

It sometimes happens to be very difficult for these organizations to inspire their members to support and work toward the successful implementation of change. Employee's reactions to change can therefore differ: instead of recognizing the benefits of change, people might just change because they fear the costs of not doing so and as a consequence exhibit negative behaviors, such as turnover, or even boycott the change effort (Neves, 2009).

Although there are many studies of organizational change, few identify the aspects of change that are salient to individuals and that influence employee attitudes (Rafferty and Griffin, 2006).This study tries to address two main issues. First to identify how employee's readiness for change (being measured as change-related self-efficacy, change appropriateness and personal valence)influence employees' ability to cope with the change. Second, to establish how employee's ability to cope with change impacton their turnover intention. The proposed model is depicted in Figure 1 below. 


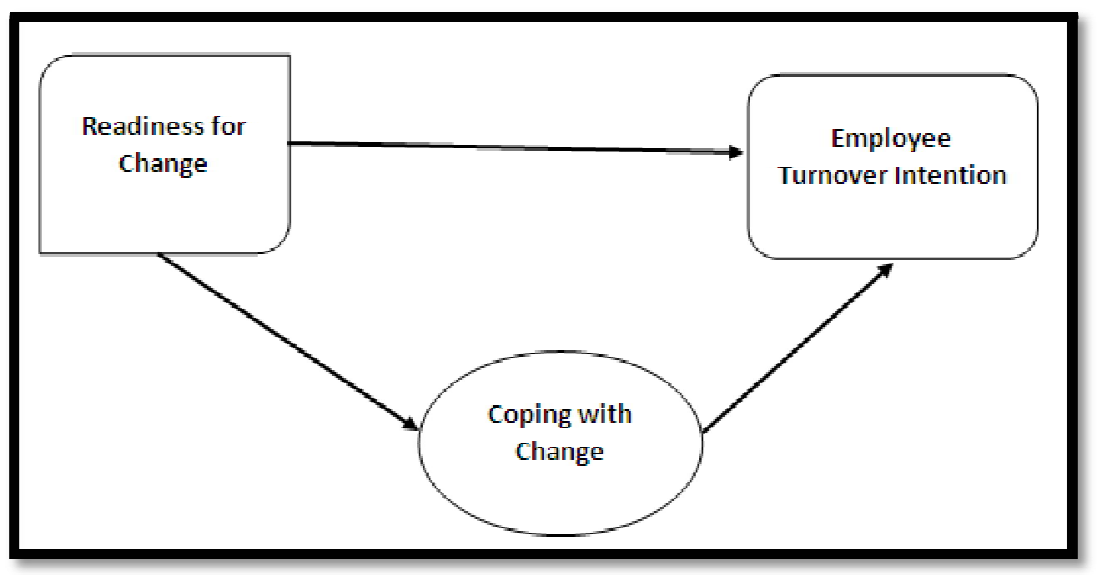

Figure 1: Proposed Model for Readiness for Change, Coping With Change and Turnover Intentions

\subsection{Readiness for Organizational Change}

According to Armenakis et al., (1993) and Hendry, (1996), evidence accumulated over a long period of time proves that, the successfulness of change effortsis due not only to their content or substantive nature but also to the processes followedor actions undertaken during their implementation. This is why it is very imperative for organizations tocreate the readiness for change among their employees by minimizing resistance and transforming employees into agents of change. Bernerth et al. (2004) provided a case study concerning a spin off that displayed the need to communicate each of the change message components. The inability to create readiness for change at a cognitive level led to speculation and rumors which ultimately resulted in resistance to change.

In order for the change to be effective, the change message should incorporate five components: (a) discrepancy ;(b) principal support; (c) self-efficacy; (d) appropriateness; and (e)personal valence (Armenakis et al., 1999).

Discrepancy focuses on the sentiment regarding whether the change is neededand is represented by an explanation of the difference between the actual stateand the desired final state (Katz and Kahn, 1978). It can depend on increased competition, changes in governmental regulations or depressed economic conditions (Armenakis et al., 1993).

Principal support focuses on whether management or higher authorities are in support of the change process. This is very necessary because the lack of management support could result in the failure of the change process. Those directly involved may not be willing to change unless they have seen a clear demonstration of support from key organizational leaders (Neves, 2009).

Self-efficacy refers to organizational members' perception regarding their confidence in their ability to cope with change effectively (Bandura, 1986). This mastery is progressive, and individuals gradually accumulate more complex skills, increasing their feelings of self-efficacy, while minimizing stress from abandoning the old behaviors (Neves, 2009). So, while creating readiness for change, one should reinforce employee's feelings of self-efficacy in order to reduce discrepancy (Armenakis et al., 1993). Bernerth (2004) proposed that during stressful times, such as organizational change, low self-efficacy presents a negative cyclical relationship in that individuals who judge themselves as incapable of coping with environmental demands will tend to dwell on personal deficiencies and magnify the severity and difficulty of the task/ change at hand, thus making it more difficult to change their own behaviors.

Appropriateness addresses whether the change activity is adequate for the organization and if individuals agree with it. It places emphasis on organizational values and whether the organizations change in accordance with such values. Finally, personal valence emphasizes the positive and negative outcomes of change, its intrinsic and extrinsic benefits, and its fairness (that is, it is in our best interest to change)(Neves, 2009).Personal valence can be operational zed through employee's affective commitment to change, since it reflects a desire to provide support for the change based on a belief on its inherent benefits (Herscovitch and Meyer, 2002). Several authors have produced a compelling rationale for using commitment in the assessment of the impact of organizational change on employee-organization relations (Becker; 1992; Becker et al., 1996; Meyer and Allen 1997).

Although readiness for change comprises five different components, the relevance and weight of each factor may depend on the type of change organizations face (Neves, 2009). According to Neves, (2009), when the change focuses primarily on the individual performance of employees for example, the role of individual and content variables such as appropriateness, self-efficacy and personal valence is enhanced. In such situations, people tend to focus on what is expected of them, if they are able to do it and whatthe consequences of change are. In the case of this study where the change focuses on the management team as well as certain organizational practices, we also expect these three dimensions of readiness for change to have a significant relationship with how individuals intend to behave, both concerning the change (how much their individual behaviors are influenced by change) and the organization in general (if they want to leave the organization).

\subsection{Coping with Change}

Coping behaviour is generally defined as "conscious psychological and physical efforts to improve one's resourcefulness in dealing with stressful events ... or to reduce external demands" (Anshel, Kim, Kim, Chang, \& Hom, 2001). Research has suggested that coping is particularly important in the organizational context of change because such 
transformations are often accompanied by uncertainty, anger, stress, and conflict at work and at home (Ashford, 1988; Schweiger \& DeNisi, 1991). The stress produced by organizational change is fundamentally owing to perceived uncertainty regarding changes in the work environment (Rafferty \&Griffin 2006). Marchione and English (1982), for example, argued that "organizations must learn to cope with change", while Cunningham et al., (2002) suggested that employees who are confident in their ability to cope with change are likely better equipped to contribute to the change process.

When coping with change employees extract clues from the environment to make sense of an event. Within this perspective, employees' perceptions and attitudes are determined by their understanding of the changing situation and the effect the changes will have on them (Lau and Woodman 1995, Fisher and Howell 2004; Bartuneket al., 2006). Ambiguity or lack of information leads employees to experience uncertainty, confusion, or doubt regarding what change means for them (DiFonzo \&Bordia 1998). Rafferty and Griffin (2006) found that regular and poorly planned changes lead to greater levels of change-related uncertainty. Undeniably, uncertainty is a commonly experienced state during organizational change (Bordia et al., 2004a). Empirical evidence indicates that uncertainty is negatively associated with many organizational attitudes (Nelson et al., 1995; Rafferty and Griffin 2006), commitment (Hui and Lee, 2000), and trust in the organization (Schweiger \&Denisi 1991) which may subsequently lead to turnover intention.

\subsection{Turnover Intention}

Turnover behaviour is a multistage process that includes attitudinal, decisional and behavioural components. The theory of planned behaviour (Ajzen, 1991) suggests that behavioural intention is a good predictor of actual behaviour. Various studies (Fox \& Fallon, 2003; Shields \& Ward, 2001; Tett \& Meyer, 1993) have successfully demonstrated that behavioural turnover intentions are consistently seen to moderate strongly with correlations of turnover, authenticating the notion of Ajzen (1991). There is considerable support for the notion, that intention to quit or stay is probably the most important and immediate individual-level antecedent and predictor of turnover decisions (Chiu \& Francesco, 2003; Fox \& Fallon, 2003). From the above, it could be inferred that the immediate precursor of behaviour is thought to be intentions, and therefore the best predictor of turnover should be intention to turnover. Mobley (1977) however suggested that there are several other possible turnover cognition types of interest to add in the withdrawal decision (the decision to quit a job), highlighting notions such as thinking of quitting, followed by the intention to search for alternatives. Furthermore, many studies have been based on the belief that turnover is an individual choice behavioural pattern based on the conceptualization that it is a psychological response (Lum, Kervin, Clark, Reid \&Sirola, 1998; Mobley, Griffeth, Hand \& Meglino, 1979). For the sake of this study, turnover intentions are seen as a mental decision (conation) intervening between an individual's attitudes (affect) regarding a job and his/ her subsequent behaviour to either stay or leave (Sager, Griffeth \& Hom, 1998).

\subsection{Relationship between Readiness for Change and Coping with Change}

As mentioned earlier, readiness for change is being measured as a three-dimensional variable (appropriateness, self- efficacy and personal valence- affective commitment). Cunningham et al. (2002), for example, found that confidence in the ability to cope with organizational change was positively related with readiness for change, participation in the change process, and perceived contribution to the change. Portraying the importance of change-specific self-efficacy, Conner (1992) suggested that individuals will not perform well in change contexts when they are not confident about their abilities. According to Armenakis et al. (1993), individuals will avoid activities believed to exceed their coping capabilities but will undertake and perform those which they judge themselves to be capable of. Bandura (1977) argued that domainspecific self-efficacy depends on the specifics of a situation and can be increased through organizational interventions that enhance mastery of the situation. Cunningham (2006) posits that commitment to change and coping with change have been presented as important factors influencing the change process. Herscovitch and Meyer (2002) suggested that two forms of commitment to change-affective and continuance-are likely to influence one's coping behaviour. With respect to affective commitment (personal valence), it is expected that persons with high levels of affective commitment to change will also be able to successfully cope with the changes taking place. Recall that people with an affective commitment to change believe in the value of the change, think that the change serves an important purpose to the organization, and view the change as an effective strategy (Herscovitch \&Meyer, 2002). If people hold such positive attitudes toward the change process, it is likely that, although the change may be stressful at times, they will be able to cope with such transitions because it ultimately benefits the company. In this way, affective commitment (personal valence) serves to "buffer the effect of change-related stress on employee health and well-being" (Herscovitch \& Meyer, 2002).Related research in the area of affective organizational commitment has provided a similar rationale. Specifically, Antonovsky (1979) argued that affective organizational commitment allows employees to withstand the effects of tension in high-stress environments, and Begley and Czajka (1993) research provided empirical evidence for this contention. Based on this literature, the following hypothesis was advanced:

- Hypothesis 1: There will be a positive relationship between Readiness for Change and Coping with Change.

\subsection{Relationship between Coping with Change and Turnover Intention}

Judge et al.(1999) found that the coping behaviour was associated with several career outcomes, including salary, organizational commitment, satisfaction, and job performance. This study suggests that employees who successfully cope with the change initiatives are more likely to contribute to that process and to realize desired career outcomes.(Lee and Mitchell 1994; Lee et al.,1996), which posits that "shocks" - anticipated or unanticipated-are events that jar employees to voluntarily decide quitting their jobs. Thus, to say that an individual's ability or inability to coping effectively with change could have an effect on both his cognition and behaviour where turnover intention and even actual turnover could 
be eminent. The process of organizational change should therefore be implemented in a more structured and professional way. It should not only focus on change management but also should ensure that individuals are empowered. It was therefore hypothesized as follows;

- Hypothesis 2: Coping with Change will be negatively associated with Turnover Intention.

\subsection{Readiness for Change, Coping with Change and Turnover Intention}

Since this study focus on how much individuals behaviour are affected by change, it is expected that the three dimensions of readiness for change to operate at different levels: when employees think they are able to cope with change (self-efficacy) and agree that change is the adequate solution for the organization (change appropriateness), they have a better understanding of the benefits of change, increasing their affective commitment to change (personal valence) and influencing their behavioral intentions. Cunningham et al.(2002) found that employees with higher job-change self-efficacy reported higher readiness for change and contributed more to the change intervention.

Neves, (2009)found that self-efficacy had a direct negative relationship with turnover intentions and this is in line with Armenakis et al.(1999) model of change, for three of the proposed dimensions, and suggest that creating readiness for change does influence individuals' behavioral intentions.

Neves, (2009) posits that, change appropriateness, self-efficacy, and personal valence in general revealed its importance for an effective adoption of change, through two distinct outcomes: by promoting individual change, in which the organization transforms its employees in change agents themselves, which later may help in the institutionalization phase, where these procedures became a part of their everyday life; and by reducing active forms of resistance to change, such as turnover intentions. Based on this literature, the following hypothesis was advanced:

- Hypothesis 3: Readiness for change will be negatively associated with turnover intention.

- Hypothesis 4: The negative relationship between Readiness for Change and Turnover Intention will be mediated by the ability to cope with Change.

\subsection{Research Context: Change in Management Team}

University of Education, Winneba, is one of the Ghanaian universities which have seen a great deal of change in its management team within the last two years. In May 2017, one Supi Kofi Kwayera commenced an action in the Winneba High Court against the University of Education, Winneba and the Minister for Education, alleging a breach of the University's Act, 2004 (Act 672) and the Public Procurement Act, 2003 (Act 663). He sought among other reliefs the declaration that the continuous existence of the Avoke-led Governing Council was "illegal" and a declaration that all appointments by the Council were void.

The applicant secured an injunction restraining the Vice-Chancellor and the Finance Officer from exercising their duties until final determination. In relation to this, the Minister of State in charge of Tertiary Education, on July 18, 2017 inaugurated a 16-member Governing Council for the University. The Governing Council in August, 2017 constituted a Factfinding Committee to acquaint the Council about the suits against the School at the Winneba High Court.

Based on the interim report submitted by the Fact-Finding Committee in October, 2017; Council asked six officers of the University to step aside. These individuals were Prof. Mawutor Avoke (Vice Chancellor), Mr. Theopilus Senyo Ackorlie (Finance Officer), Frank Owusu Boateng (Deputy Finance Officer), Ms Sena Dake (Internal Auditor), Mary Dzimey (Ag. Head of Procurement) and Daniel Tetteh (Ag. Deputy Director of Works \& Physical Development).

The then Pro-Vice Chancellor, Rev. Prof. Afful-Broni was ask by the newly inaugurated Council to act in the stead of the Vice-Chancellor until a determination of the suit in Court against the Prof Avoke-led Governing Council. The Ag. Vice Chancellor was eventually confirmed as the substantive Vice Chancellor in September, 2018 while the other five officers were replaced.

\section{Methodology}

\subsection{Sample and Procedure}

The population for the study was employees of University of Education, Winneba, which has seen various changes in its management team and policies within the past year. The university has a staff population of 719 which is made up of 454 teaching and 265 non- teaching staff as at April 2018. 150 research questionnaires were distributed using the convenient sampling technique. Out of this, 107 responses, which is made up of 40 teaching and 67 non- teaching staff were obtained (71\% response rate).Questionnaires were distributed and collectedby the help of a research assistant who was coached to ensure anonymity.

\subsection{Measures}

Readiness for change was measured using a combined scale of self- efficacy, change appropriateness and affective commitment as illustrated by Neves, (2009) and the Cronbach's alpha value of 0.901 was obtained.

Coping with change was measured with a twelve-item scale. Items on the scale include; 'I often find myself leading change efforts in this company'; 'The changes occurring in this company cause me stress' and 'When dramatic changes happen in this company, I feel I handle them with ease'. (Cronbach's alpha 0.609).

Turnover intention was measured with a four-item scale developed by Mak and Sockel (1999). Items include; 'I am actively/ passively looking for another job outside my company's'; 'T would consider leaving for a company that has excellent project management'; 'I would seriously consider leaving for even a slightly better position elsewhere' and 'I 
would seriously consider leaving my job for a position where I could earn more'.(Cronbach's alpha 0.902).All scales were measured on a five- point Likert scale where $1=$ totally disagree and $5=$ totally agree.

\section{Results}

\subsection{Descriptive Statistics}

\begin{tabular}{|c|c|c|c|c|}
\hline Scale & No. Items & Mean & Standard Deviation & C. Alpha \\
\hline Readiness for Change (RFC) & 10 & 3.459 & 0.739 & 0.901 \\
Personal Valence(PV) & 3 & 3.710 & 0.984 & 0.927 \\
Change Appropriateness (CA) & 4 & 3.325 & 0.859 & 0.886 \\
Self-Efficacy (SE) & 3 & 3.386 & 0.695 & 0.600 \\
\hline Coping with Change (CWC) & 12 & 3.111 & 0.421 & 0.609 \\
\hline Turnover Intention (TI) & 4 & 2.904 & 1.125 & 0.902 \\
\hline
\end{tabular}

Table 1: Descriptive Statistics and Cronbach Alpha Values

Table 1 presents the descriptive statistics as well as the reliability values of items used in the study. The items used showed very good internal consistency ranging from 0.60 to 0.927 . The mean and standard deviation values also ranged from 2.904 to 3.710 and 0.421 to 1.125 respectively.

\subsection{Correlation Analysis}

To test the hypotheses of the study, data was analyzed using Pearson's correlation analysis. The purpose of the analysis is to relate the various independent variables (Readiness for Change and Coping with Change) with the dependent variable (Turnover Intention). The correlation matrix as presented in Table 2 below, show the degree of association between the various variable of the study that is readiness for change, coping with change and turnover intention. It is observed that, readiness for change had significantly and positively associated with coping with change $(r=476, p<0.01)$. Readiness for change is also found to be significantly negatively related to turnover intention $(r=-.191, p<0.05)$. However, coping with change was seen not to be significantly related to turnover intention.

\subsection{Correlation Matrix}

\begin{tabular}{|c|c|c|}
\hline & Readiness for change (RFC) & Coping with change (CWC) \\
\hline Readiness for change (RFC) & $.476^{* *}$ & \\
\hline Coping with change (CWC) & $-.191^{*}$ & -.122 \\
\hline Turnover intention (TI) & The & \\
\hline
\end{tabular}

Table 1: Descriptive Statistics and Cronbach Alpha Values

Note: $\mathrm{N}=107, * \mathrm{P}<0.05, * * \mathrm{P} \varangle 0.01$

\subsection{Regression Analysis}

A linear regression analysis was further conducted to determine the impact of the independent variable on the dependent variable. Table $3 \& 4$ presents the output from the linear regression analysis.

\begin{tabular}{|c|c|c|c|c|c|c|}
\hline Predictor & $\mathbf{R}$ & $\mathbf{R}^{\mathbf{2}}$ & Adj. R & $\mathbf{F}$ & Sig. & $\boldsymbol{\beta}$ \\
\hline Readiness for Change & .191 & .036 & .027 & 3.978 & .049 & $-.191^{*}$ \\
\hline
\end{tabular}

Table 3: Readiness for Change and Turnover Intention

Notes: Dependent Variable $=$ Turnover Intention, $* \mathrm{P} \varangle 0.05$

As shown in Table 3 above, the F statistics of 3.978 with a probability value of 0.049 less than 0.05 indicates the significance of the regression model in explaining the changes in turnover intention. Additionally, the coefficient of determination which is the R-square value of 0.036 implies that 3.6 percent of the changes in turnover intention are explained by the regression model. This implies that readiness for change significantly predicts turnover intention of employees.

\begin{tabular}{|c|c|c|c|c|c|c|}
\hline Predictor & $\mathbf{R}$ & $\mathbf{R}^{\mathbf{2}}$ & Adj. $\mathbf{R}^{\mathbf{2}}$ & $\mathbf{F}$ & Sig. & $\boldsymbol{\beta}$ \\
\hline Readiness for Change & .476 & .227 & .219 & 30.519 & .000 & $.476^{*}$ \\
\hline
\end{tabular}

Table 4: Readiness for Change and Coping with Change

Notes: Dependent Variable $=$ Coping With Change, $* \mathrm{P} \varangle 0.05$

Table 3 above also shows a significant predictability of readiness for change and coping with change. This is shown from the F statistics of 30.519 with a probability value of 0.000 less than 0.05 indicates the significance of the regression model in explaining the changes in coping with change. Additionally, the coefficient of determination which is the R-square value of 0.227 implies that 22.7 percent of the changes in coping with change are explained by an employee's readiness for change. 


\begin{tabular}{|c|c|c|c|c|c|c|}
\hline Predictor & $\mathbf{R}$ & $\mathbf{R}^{2}$ & Adj. $R^{2}$ & $\mathbf{F}$ & Sig. & $\beta$ \\
\hline & \multirow[t]{3}{*}{.194} & \multirow[t]{3}{*}{.038} & \multirow[t]{3}{*}{.019} & \multirow{3}{*}{2.013} & & \\
\hline Readiness for Change & & & & & .122 & -.171 \\
\hline Coping with change & & & & & .714 & -.040 \\
\hline
\end{tabular}

Table 5: The Mediating Effect of Coping with Change

Notes: Dependent Variable $=$ Turnover Intention, $* \mathrm{P} \varangle 0.05$

From Table 3 above, it is observed that the independent variable (Readiness for Change) significantly predicts the dependent variable (Turnover Intention) with $\beta$ value of- 0.191 and a p-value of 0.49 and Table 5 shows an insignificant coefficient value of the relationship between the independent variable (Readiness for Change) and the dependent variable (Turnover Intention) when the mediating variable (Coping with Change) is introduced in the model. The $\beta$ value was 0.171 with a p-value of 0.122 . This indicates that Coping with Change is not a significant mediator in the relationship between Readiness for Change and Turnover Intention.

\section{Summary of Hypotheses}

Table 6 provides a summary of all four hypotheses tested.

\begin{tabular}{|c|l|c|}
\hline Hypothesis 1 & $\begin{array}{l}\text { There will be a positive relationship between Readiness for Change and } \\
\text { Coping with Change. }\end{array}$ & Confirmed \\
\hline Hypothesis 2 & $\begin{array}{l}\text { Coping with Change will be negatively associated with Turnover } \\
\text { Intention }\end{array}$ & Rejected \\
\hline Hypothesis 3 & $\begin{array}{l}\text { Readiness for Change will be negatively associated with Turnover } \\
\text { Intention. }\end{array}$ & Confirmed \\
\hline Hypothesis 4 & $\begin{array}{l}\text { The negative relationship between Readiness for Change and Turnover } \\
\text { Intention will be mediated by the ability to Cope with Change. }\end{array}$ & Rejected \\
\hline
\end{tabular}

Table 6: Summary of Hypotheses

\section{Discussion}

As indicated in our conceptual model, an employee's level of readiness for change should be related his or her turnover intention and this relationship should be mediated by the individual's ability to cope with the change that occurs. The data derived from our research confirm this, as readiness for change display a significant positive correlation with coping with change and a significant negative correlation with turnover intention. The negative relationship between readiness for change and turnover intention was also found to be mediated by the individual's ability to cope with the change. Coping with change was however observed to have no significant correlation with employee's turnover intention. These findings confirm earlier studies by Cunninghamet al.(2002), who found that confidence in the ability to cope with organizational change was positively related with readiness for change, participation in the change process, and perceived contribution to the change. Conner (1992) also suggest that individuals will not perform well in change contexts when they are not confident about their abilities. According to Armenakis et al.(1993), "individuals will avoid activities believed to exceed their coping capabilities but will undertake and perform those which they judge themselves to be capable of.This proves that for a change process to be successful, the recipient of the change process should be adequately read for the change program. Thus, they should see the relevance or need for the change (change appropriateness), believe in their ability to deal with the change and be committed to the change (personal valence).

Our findings are in further conformity with that of Neves, (2009) who found that self-efficacy had a direct negative relationship with turnover intentions and this is in line with Armenakis et al. (1999) model of change, which suggests that creating readiness for change does influence individuals' behavioral intentions. Cunningham et al. (2002) found that employees with higher job-change self-efficacy reported higher readiness for change and contributed more to the change intervention. Neves, (2009) also posits that, change appropriateness, self-efficacy, and personal valence (readiness for change) in general revealed its importance for an effective adoption of change, through two distinct outcomes: by promoting individual change, in which the organization transforms its employees in change agents themselves, which later may help in the institutionalization phase, where these procedures became a part of their everyday life; and by reducing active forms of resistance to change, such as turnover intentions. According to Phillips (1998), it is therefore important that organisations should communicate not only an idealized vision of the change process to employees. This results in the development of unrealistic expectations surrounding the change and consequently disappointment. Organisations should instead communicate a realistic picture of the proposed change, thereby enabling employees to cope better with the proposed change and suffer fewer disappointments (Lines 2005). This realistic portrayal of the change might improve feelings of personal valence and organizational valence, resulting in improved levels of change readiness

The findings of this study were however at disparity with that of Lee and Mitchell (1994) and Lee et. al. (1996), who posits that "shocks" - anticipated or unanticipated-are events that jar employees to voluntarily decide quitting their jobs. Thus, to say that an individual's ability or inability to coping effectively with change could have an effect on both his cognition and behaviour where turnover intention and even actual turnover could be eminent. Judge et al.(1999) also found that the coping behaviour was associated with several career outcomes, including salary, organizational commitment, satisfaction, and job performance. He suggests that employees who successfully cope with the change 
initiatives are more likely to contribute to that process and to realize desired career outcomes. Schweiger and DeNisi, (1991) have also suggested that coping is particularly important in the organizational context of change because such transformations are often accompanied by uncertainty, anger, stress, and conflict at work and at home. This may be explained to be as a result of the high unemployment rate in the Ghanaian economy and the favourable working conditions that exist in the Ghanaian public sector from which our sample was drawn. It could be argued that because of the difficulty involved in getting employed, most people try to ignore the kind of stress happening in their organizations especially in the public sector where there are relatively favourable work conditions as compared to the private sector and as such do not consider leaving the organization.

\section{Conclusion}

As indicated by the research, change readiness correlates with both coping with change and turnover intention. Since change readiness is informed by personal valence, self- efficacy and change appropriateness, it is important that change management practitioners stimulate the development of these elements among employees during times of change to help make the change process a success. This can be done by ensuring that adequate information (both favourable and unfavourable) are well communicated to the employees and where necessary training provided.

As By et al.(2008) mentioned, not all changes initiated are required or are even in the best interest of an organization but are based on personal/ political interests. As such, it is imperative to fashion and disseminate a resilient message for change and prove to the involved parties that it is in the greatest interest of all to change in the projected direction. This proves that managers are significant actors in stimulating spirits of readiness for change in their employees and when the change message is carefully crafted, the organization will experience its benefits, thus, successfully adopting and institutionalizing change.

\section{Recommendations and Limitations}

The findings of this research suggest several avenues for future research. Readiness for change and coping with change appear to be useful areas for continued examination since change has become a constant phenomenon in today's business world; it is for that reason that it is significant to explore the influence of the two variables on employees' performance and commitment level.

It should also be noted that our research was conducted just one year after the change in management was implemented at the University using the quantitative survey method. Future research using a change model incorporating causal, intervening and outcome variables would benefit from adopting a longitudinal approach. This will allow for the measurement of all variables prior to, during and after the change is implemented in order to establish whether the relationships between and among variables observed in the study remain consistent throughout the change process. A longitudinal approach would also allow researchers to test assumptions regarding the direction of causality.

\section{References}

i. Ajzen, I. (1991). The theory of planned behaviour. Organizational Behaviour and Human

ii. Decision Processes, 50(2), 179-211.

iii. Anshel, M. H., Kim, K. W., Kim, B. H., Chang, K. J., \& Hom, H. J. (2001). A model for coping with stressful events in sport: Theory, application, and future directions. InternationalJournal of Sport Psychology, 32, 43 - 75.

iv. Antonovsky, A. (1979). Health, stress, and coping. San Francisco: Jossey-Bass.

v. Armenakis, A.A., Harris, S.G. and Field, H.S. (1999) Making change permanent: a model for institutionalizing change interventions, in: W. Pasmore and R. Woodman (eds) Research in Organizational Change and Development, vol. 12, pp. 97-128 (Stamford, CT: JAI Press).

vi. Armenakis, A.A., Harris, S.G. and Mossholder, K.W. (1993) Creating readiness for organizational change, Human Relations, 46(6), pp. 681-703.

vii. Ashford, S. J. (1988). Individual strategies for coping with stress during organizational transitions. Journal of Applied Behavioral Science, 24, 19 - 36.

viii. Bandura, A. (1977). Self-efficacy: Toward a unifying theory of behavioral change. Psychological Review, 84, 191215.

ix. Bandura, A. (1986) Social Foundations of Thought and Action: A Social Cognitive Theory(Englewood Cliffs, NJ: Prentice-Hall).

x. Bartunek, J. M., Rousseau, D. M., Rudolph, J. W., \& DePalma, J. A. (2006). On the receiving end: Sense making, emotion, and assessments of an organizational change initiated by others. The Journal of Applied Behavioral Science, 42, 182-206.

xi. Becker, T.E. (1992) Foci and bases of commitment: are they distinctions worth making? Academy of Management Journal, 35(1), pp. 232-244.

xii. Becker, T.E., Billings, R.S., Eveleth, D.M. and Gilbert, N.W. (1996) Foci and bases of commitment: implications for performance, Academy of Management Journal, 39, pp. 464-482.

xiii. Begley, T. M., \& Czajka, J. M. (1993). Panel analysis of the moderating effects of commitment on job satisfaction, intent to quit, and health following organizational change. Journal of Applied Psychology, 78, 552 - 556.

xiv. Bernerth, J.B., Armenakis, A.A., Field, H.S. and Walker, H.J. (2004) Justice, cynicism, and commitment: a study of important organizational change variables, The Journal of Applied Behavioral Science, 43(4), pp. 303-326.

xv. Bordia, P., Hobman, E., Jones, E., Gallois, C., \& Callan, V. J. (2004a). Uncertainty during organizational change: Types, consequences, and management strategies. Journal of Business and Psychology, 18, 507-532. 
xvi. Bureau of National Affairs. (1996). Special survey report: Human resources outlook. Washington, DC: Author.

xvii. Conner, D.R. (1992) Managing at the Speed of Change: How Resilient Managers Succeed and Prosper Where Others Fail (New York: Villard Books).

xviii. Cunningham, G.B. (2006) The relationships among commitment to change, coping with change, and turnover intentions, European Journal of Work and Organizational Psychology, 15(1), pp. 29-45.

xix. Cunningham, C.E., Woodward, C.A., Shannon, H.S., MacIntosh, J., Lendrum, B., Rosenbloom, D. and Brown, J. (2002) Readiness for organizational change: a longitudinal study of workplace, psychological and behavioural correlates, Journal of Occupational and Organizational Psychology, 75(4), pp. 377-392.

xx. Chiu, R.D. \& Francesco, A.M. (2003). Dispositional traits and turnover intention: Examining the mediating role of job satisfaction and affective commitment. International Journal of Manpower, 24(3), 284-298.

xxi. DiFonzo, N., \& Bordia, R. (1998). A tale of two corporations: Managing uncertainty during organizational change. Human Resource Management, 37, 295-303.

xxii. Dyer, W.G. (1985) The cycle of cultural revolution in organizations, in: R. Kilmann, M.J. Saxton and R. Serpa (eds) Gaining Control of the Corporate Culture, pp. 200-229 (San Francisco/ London: Jossey-Bass).

xxiii. Fisher, S. L., \& Howell, A. W. (2004). Beyond user acceptance: An examination of employee reactions to information technology systems. Human Resource Management, 43, 243-258

xxiv. Fox, S.R. \& Fallon, B.J. (2003). Modeling the effect of work/ life balance on job satisfaction and turnover intentions. Symposium paper presented at the 5th Australian Industrial and Organizational Psychology Conference, Melbourne, Australia.

xxv. Hendry, C. (1996) Understanding and creating whole organizational change through learning theory, Human Relations, 49, pp. 621-641.

xxvi. Herscovitch, L., \& Meyer, J. P. (2002). Commitment to organizational change: Extension of a three-component model. Journal of Applied Psychology, 87, 474-487.

xxvii. Hui, C., \& Lee, C. (2000). Moderating effects of organization-based self-esteem on organizational uncertainty: Employee response relationships. Journal of Management, 26, 215-232.

xxviii. Judge, T.A., Thoresen, C.J., Pucik, V. and Welbourne, T.M. (1999) Managerial coping with organizational change: a dispositional perspective, Journal of Applied Psychology, 84(1), pp. 107-122.

xxix. Katz, D. and Kahn, R. (1978) The Social Psychology of Organizations (New York: John Wiley).

xxx. Lee, T. W., \& Mitchell, T. R. (1994). An alternative approach: The unfolding model of voluntary turnover. Academy of Management Review, 19, 51-89.

xxxi. Lee, T. W., Mitchell, T. R., Wise, L., \& Fireman, S. (1996). An unfolding model of voluntary turnover. Academy of Management Journal, 39, 5-36.

xxxii. Lines, R. 2005. The structure and function of attitudes towards organizational change', Human Resource Development Review, 4(1): 8-32.

xxxiii. Lum L., Kervin J., Clark K., Reid F. \& Sirola W. (1998) Explaining nursing turnover intent: job satisfaction, pay satisfaction, or organizational commitment? Journal of Organizational Behavior 19, 305-320.

xxxiv. Mak \& Sockel, (1999). "A Confirmatory Factor Analysis of IS Employee Motivation \&Retention”. Information \& Management. Vol. 38, 265-276.

xxxv. Marchione, A. R., \& English, J. (1982). Managing the unpredictable: A rational plan for coping with change. Management Review, 71(2), 52 - 57.

xxxvi. Meyer, J.P. and Allen, N.J. (1997) Commitment in the Workplace: Theory, Research, and Application (Thousand Oaks, CA: Sage).

xxxvii. Mobley, W. H. (1977). Intermediate linkages in the relationship between job satisfaction and job turnover. Journal of Applied Psychology, 62, 237-240.

xxxviii. Mobley, W.H., Griffeth, R.W., Hand, H.H. \& Meglino, B.M. (1979). Review and conceptual analysis of the employee turnover process. Psychological Bulletin, 36(3), 493-521.

xxxix. Nelson, A., Cooper, C. L., \& Jackson, P. R. (1995). Uncertainty amidst change: The impact of privatization on employee job satisfaction and well-being. Journal of Occupational and Organizational Psychology, 68, 57-71.

xl. Neves, P., (2009) Readiness for Change: Contributions for Employee's Level of Individual Change and Turnover Intentions, Journal of Change Management, 9:2, 215-231,

xli. Phillips, J.M. 1998. 'Effects of realistic job previews on multiple organizational outcomes: A meta- analysis', Academy of Management Journal, 41: 673-691.

xlii. Rafferty, A. E., \& Griffin, M. A. (2006). Perceptions of organizational change: A stress and coping perspective. Journal of Applied Psychology, 91, 1154-1162.

xliii. Sager, J.K., Griffeth, R.W. \& Hom, P.W. (1998). A comparison of structural models representing turnover cognitions. Journalof Vocational Behaviour, 53(2), 254-273.

xliv. Schweiger, D. M., \& DeNisi, A. S. (1991). Communication with employees following a merger: A longitudinal field experiments. Academy of Management Journal, 34, 110-135.

xlv. Shields, M.A. \& Ward, M. (2001). Improving nurse retention in the National Health Service in England: The impact of job satisfaction on intentions to quit. Journal of Health Economics, 20(5), 677-701.

xlvi. Tett, R.P. \& Meyer, J.P. (1993). Job satisfaction, organizational commitment, turnover intentions, and turnover: Path analyses based on meta-analytic findings. Personnel Psychology, 46, 259-293. 